\title{
The initiation stage of Food Court Waste during air versus steam gasification processes
}

\author{
Raluca Nicoleta Tîrtea, Cora Bulmău*, Gabriela Ionescu, Cosmin Mărculescu \\ University Politehnica of Bucharest, Department of Energy Production and Use, \\ Splaiul Independenţei 313, Romania
}

\begin{abstract}
Using different gasification agents: air and steam, two types of gasification process were performed into a batch reactor at temperature of $750^{\circ} \mathrm{C}$ and $850^{\circ} \mathrm{C}$ and atmospheric pressure. The only difference between of the two compared experimental configurations was represented by the gasification agent used in the process. The amount of oxygen introduced into the reactor for air gasification at an ER of 0.3 was computed. Therefore, in the steam gasification process, the same amount of oxygen was introduced, so establishing an unordinary steam to biomass ratio. In this way, the two processes, air vs. steam gasification, were compared, the rest of the process parameters being kept constant. This paper approaches the transitory regimes (initiation stage) of gasification process in order to observe the influence of process temperature and gasification agent on the process run. According to the experimental results, better gas quality is obtained if steam is used as a gasifying agent, yet the conversion and energy efficiencies decreases. By optimizing time residence in steam gasification, process efficiencies may be increased.
\end{abstract}

\section{Introduction}

Each year, the world's population generates more than 2 billion tons of waste [1]. By 2050, the world's population is expected to exceed 9 billion people [2]. So, if the society continues to keep the actual trend, in high-income countries, the waste generation will reach at 7 billion tons per year by 2025 [1]. In most of the countries the landfills continue to remain the main method for solid waste disposal [3,4]. According to several studies, solid waste generation is increasing faster than any other environmental pollutant, including $\mathrm{CO}_{2}$ [5-7].

Food waste represents a significant fraction of municipal solid waste, that requires proper management with minimum environmental impact. with According to Food and Agricultural Organization (FAO), food waste and the losses related from this waste segment accounts for $8 \%$ of global greenhouse gas emissions. Currently, in the EU, around 88 million tons of food waste are generated annually [6]. Therefore, there is a continuing interest in management waste plans development that includes drastically diminish waste

* Corresponding author: cora4cora@gmail.com 
landfilling. Food waste has a great potential in the energy field as a feedstock and represents a serious advantage that implies energy recovery due to its notable energy content [7]. This type of waste could potentially be converted to various forms of useful energy through thermochemical processes such as gasification, solving the waste landfill binding targets. Gasification of waste is preferred over combustion because it provides gas product, syngas, that can be used in many energetic applications, as rival for hot combustion gases. In gasification technology, the gas is usually composed by carbon monoxide $(\mathrm{CO})$, hydrogen $\left(\mathrm{H}_{2}\right)$, carbon dioxide $\mathrm{CO}_{2}$ and methane $\left(\mathrm{CH}_{4}\right)[8,9]$. There are abundant examples of studies that aim to optimize the gasification conditions using thermal and catalytic treatments in order to improve the gas quality by reducing the tar content in the syngas $[10,11]$, along with the hydrogen content increase and the processing stages reduction. Starting from the analysis of the gasification transitory regime, the process steps can be delimited time approximately, the composition of the gas produced at each stage can be determined, and the efficiency of the material conversion and also the process can be estimated according to the studied parameters [12].

Since for batch gasification experiments in the transitory regime, the process is not complete, like in the case of a continuous gasification process, the results could not be used to predict the final composition of the gas resulted from the process and just a primary composition of it. Therefore, the proposed approach aims to investigate the initiation stage of the gasification processes and serves as a starting point for obtaining the optimal process parameters necessary to initiate the gasification of various materials studied, under specific conditions. For this, two types of experimental gasification surveys were conducted using a batch reactor at temperatures of $750^{\circ} \mathrm{C}$ and $850^{\circ} \mathrm{C}$ and atmospheric pressure, using air and steam. To assess the gasification process in terms of gas quality, the gas composition and its lower calorific value were analyzed. Based on the experimental results, the process efficiencies can be calculated, even if the experiments do not reproduce a continuous gasification process. Their values are significantly different comparing with those obtained for a typical gasification process, but these can be used to characterize the gasification processes and to observe the influence of parameters on process run.

\section{Material and methods}

The feedstock used in the current gasification processes was food court waste (FCW). The organic material has been collected from a food court area existing in a commercial center. Its composition keeps the standard values of the concentration for all the components and the characteristics of a FCW residue. More details about the collection stage, pretreatment and characterization were previously reported by the authors in $[11,13]$.

Experiments of air/steam gasification of FCW - transitory regime - were conducted at atmospheric pressure, while the process temperature was set at $750^{\circ} \mathrm{C}$ or $850^{\circ} \mathrm{C}$. For the air gasification experiments an ER of 0.3 was considered, therefore the amount of oxygen introduced in the reactor was computed. The amount of water introduced in the reactor was calculated to ensure the equivalent oxygen as for the air gasification process. In order to compare the two processes, air versus steam gasification, all process parameters were maintained constant. The amount of oxygen introduced in the process, supplied either from air or from water, was kept constant. The description of the experimental setup procedure concerning gasification using air was already reported by the authors in another research study $[11,21]$. The experimental steps are like those depicted in Figure 1, except the gasifying agent, steam in this case. Therefore, water was introduced in the reactor at a constant and controlled flow rate, using an automatic syringe injection pump manufactured by Indiamart, model 300 . 


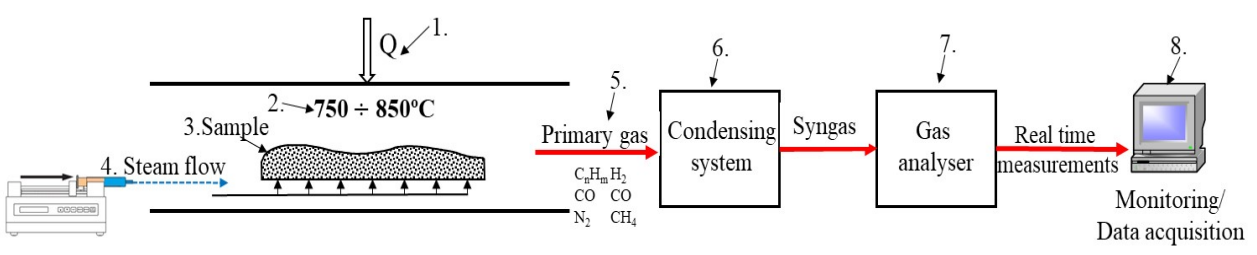

Figure 1. Air/Steam gasification experimental set-up (adopted after [11, 12, 14 -16])

1. Externally heated batch reactor; 2. Temperature controller $\left(750^{\circ} \mathrm{C}-850^{\circ} \mathrm{C}\right) ; 3$. Food Courte Waste sample; 4. Syringe Pump (Steam flow); 5. Gas line outlet (primary gas); 6. Cooling systems with water-cooled ice; 7. Testo 350 XL gas analyser; 8. Data monitoring and acquisition: EASY- emission software, Testo, Inc.

In the following, the main parameters related to the process gasification. are defined and explained.

Carbon conversion efficiency represents the ratio between the amount of carbon in gas products and the amount of carbon introduced in the process by fuel $[17,18]$ :

$$
C C E=(\text { Carbon in gasification products / Carbon in fuel) } \cdot 100[\%]
$$

or it can be computed by considering the amount of carbon unburned $[19,20]$ :

$$
C C E=(1-\text { Carbon in ash / Carbon in fuel }) \cdot 100[\%]
$$

For the CCE computation, data such as product gas composition, the amount of substance produced (expressed in $\mathrm{kmol}$ ), the amount of carbon in gas products etc. must be known. For the determination of the amount of gas produced, two methods may be applied:

- First method (1): determining the quantity of gas produced in mass units by mass balances, and the gas molar mass;

- Second method (2): determining according to Basu, by Nitrogen conservation of mass [19].

To compute the CCE, it is imperative to know the amount of gas produced, expressed in kmol. Therefore, by applying the two methods described above, two values for CCE will result and they may be similar.

Cold-gas efficiency (CCE) is the ratio between the chemical energy of the produced gas and the chemical energy of the gasified material, thus [17-20]:

$$
\mathrm{CGE}=\left(\mathrm{LHV}_{\text {gas }} \cdot \mathrm{M}_{\text {gas }} / \mathrm{LHV}_{\text {fuel }} \cdot \mathrm{M}_{\text {fuel }}\right) \cdot 100[\%]
$$

where $\mathrm{LHV}_{\text {gas }}$ - lower calorific value of gas $[\mathrm{kJ} / \mathrm{kg}], \mathrm{LHV}_{\text {fuel }}$ - lower calorific value of feedstock $[\mathrm{kJ} / \mathrm{kg}], \mathrm{M}_{\text {gas }}$ - mass of gas produced from the gasification of $\mathrm{M}_{\text {fuel }}$ [kilograms of fuel].

The gasification processes take place at high process temperatures; therefore, the gas temperature and its sensible heat are very high. If the gas produced through gasification is used in applications such as ovens or boilers, the gas sensible heat energy can be used. Therefore, hot-gas efficiency (HGE) can be defined, since, besides its gas chemical energy, it also takes into account the sensible heat of the gas produced $[17,18,20]$ :

$$
\mathrm{HGE}=\left(\left(\mathrm{LHV}_{\text {gas }} \cdot \mathrm{M}_{\text {gas }}+\mathrm{M}_{\text {gas }} \cdot \mathrm{c}_{\text {pgas }} \cdot\left(\mathrm{T}_{\text {gas }}-\mathrm{T}_{\text {fuel }}\right)\right) /\left(\mathrm{LHV}_{\text {fuel }} \cdot \mathrm{M}_{\text {fuel }}\right)\right) \cdot 100[\%]
$$

where $\mathrm{c}_{\text {pgas }}$ - specific heat of gas $[\mathrm{kJ} / \mathrm{kgK}], \mathrm{T}_{\text {gas }}$ - gas temperature at the gasification reactor outlet $\left[{ }^{\circ} \mathrm{C}\right]$, and $\mathrm{T}_{\text {fuel }}$ - fuel temperature entering the gasification reactor $\left[{ }^{\circ} \mathrm{C}\right]$. 


\section{Results and discussions}

In the figure below, variations of $\mathrm{CO}$ and $\mathrm{H}_{2}$ concentrations from the syngas function of the process parameters are presented in case of the air vs. steam FCW gasification. It can be observed that neither the process temperature, nor the gasification agent does not influence the concentration of $\mathrm{CO}$ in the analyzed temperature range. On the other hand, the $\mathrm{H}_{2}$ concentration is influenced by both process temperature and gasification agent in case of air vs. steam gasification processes at a temperature of $850^{\circ} \mathrm{C}$. Using steam in gasification processes leads to $\mathrm{H}_{2}$ concentration increase by 3 percentage points, compared to air gasification at $850^{\circ} \mathrm{C}$.

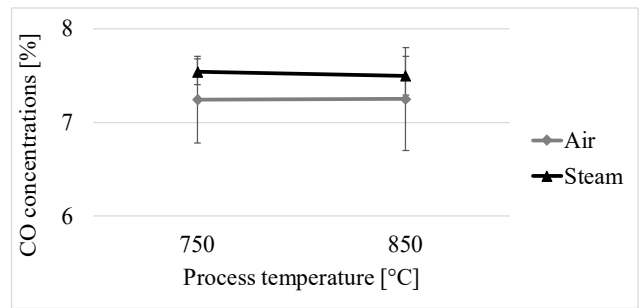

Figure 2. Variation of CO concentration - air vs. steam gasification of FCW

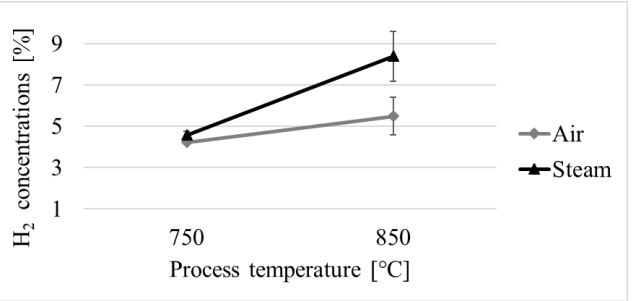

Figure 3. Variation of $\mathrm{H}_{2}$ concentration - air vs. steam gasification of FCW

Figure 4 and Figure 5 illustrate the CCE variation for air vs. steam gasification processes of FCW function of the process temperature and type of oxidant. CCE has different values, depending on the method for the gas quantity determination. For the air gasification processes, CCE increases slightly with temperature rise and decreases slowly with temperature rise for the FCW steam gasification processes. Concerning the method applied for the gas quantity determination, the obtained values of the CCE are considerably lower when steam is used.

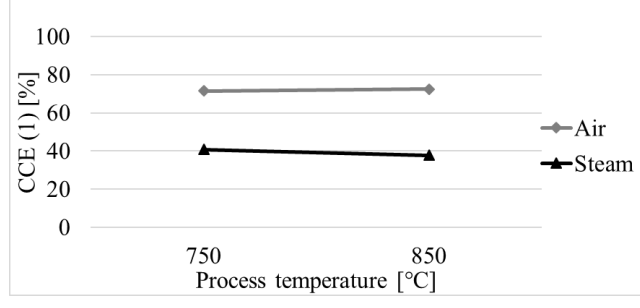

Figure 4. CCE (1) - air vs. steam gasification of FCW

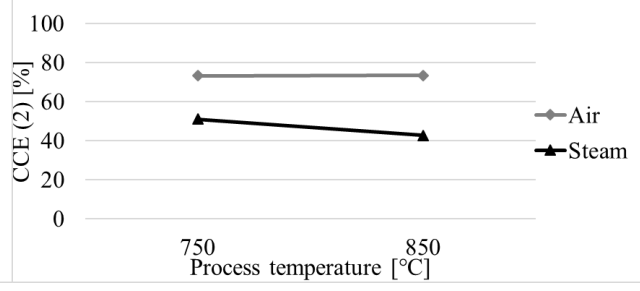

Figure 5. CCE (2) - air vs. steam gasification of FCW

In the figures below the variation of CGE and HGE function of the process parameters for air vs. steam gasification processes of FCW are presented. The calculated energy efficiencies are influenced both by process temperature and type of oxidant. Regarding the type of the oxidant used in the process, energy efficiencies increase with the process 
temperature rise, in the range considered. Similar to CCE, CGE and HGE decrease when steam is used as an gasification agent.

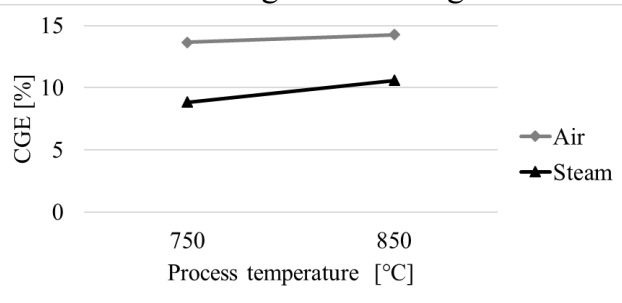

Figure 6. CGE - FCW air vs. steam gasification

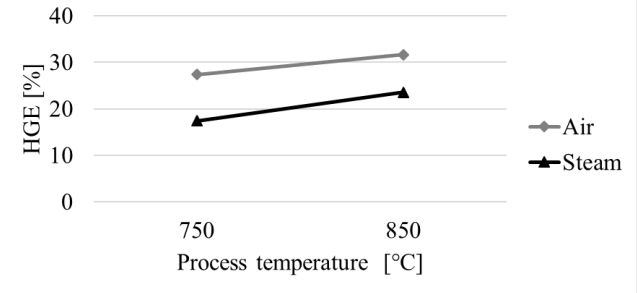

Figure 7. HGE - FCW air vs. steam gasification

CGE and HGE decrease by approximately 3-5, respective, by 8-10 percentage points, when steam is used in the process. The process temperature increase by $100^{\circ} \mathrm{C}$ leads to an optimization of CGE of maximum 2 percentage points, while HGE increases by 6-8 percentage points.

Char gasification step is the most important stage in gasification processes since heterogenous reactions between gas and solid phase takes place, therefore this step determines gasification process duration. The reaction between solid carbon and oxygen (air) is very fast, whereas oxygen is the most reactive oxidizing. Reaction between steam and solid carbon is 3 to 5 magnitude orders slower [17]. Therefore, in steam gasification processes, residence time must be increased, compared to air gasification process, to ensure enough time for reaction to take place. Since process duration was maintained constant in the air vs. steam gasification experiments conducted, the conversion efficiencies decreased in steam gasification.

According to mass balance, the amount of gas produced in air gasification of FCW varied between 95.19 and $96.93 \%$, while the gas produced from steam gasification of FCW was $87.41-91.27 \%$, depending of process temperature. The decrease in the amount of gas produced is also a consequence of the short residence time.

\section{Conclusions}

When the air is used as a gasification agent, the gas production exceeds $95 \%$. The experimental results showed that the production of gas is intensively influenced by the process temperature, increasing with temperature rise. Also, high gasification temperatures favor the solid material conversion into gas.

Concerning the steam gasification processes, the gas production is sometimes less than $90 \%$. The use of the steam as gasification agent caused also a decrease of the CCE. The results of the gasification experiments demonstrated that the CCE tends to increase when the temperature and air equivalence ratio are rising. Higher process temperatures provide a higher reaction rate, the greater amount of air introduced in the process producing more oxygen in the reactor, which can be used for carbon oxidation reactions.

The values obtained for CGE and HGE are smaller compared to those generated by the standard gasification processes, due to the type of the experiments performed in our study. So, a complete gasification process does not take place in the laboratory reactor used in this case. Thus, the energy efficiencies values are calculated based on the intermediate gas compositions, representing the efficiencies of some gasification process stages, not of the whole process. However, the calculated values of the energy efficiencies can be used to characterize the gasification processes and to observe the influence of the process parameters on the obtained gas. Usually, the difference between CGE and HGE in a typical 
gasification process is about $10-20$ percentage points. This range is keeping also for the gasification processes performed for the already mentioned conditions.

Based on the experimental results of our study, we can conclude that better values for CGE and HGE are generated when the air is used as an gasification agent, but taking into account the gas composition, better gas compositions are obtained when the steam is used as a gasifying medium. Therefore, for better overall results, steam gasification of FCW at an increased time residence should be studied.

\section{Acknowledgement}

Funding provided through Romania's "Competitiveness Operational Programme 2014-2020" Priority Axis 1: Research, Technological Development and Innovation (RD\&I) to Support Economic Competitiveness and Business Development Action 1.1.4. Attracting high-level personnel from abroad in order to enhance the RD capacity ID/Cod My SMIS: P_37_768/103651; No. Contract: 39/02.09.2016

\section{References}

1. Solid Waste Management in the World's Cities, Water and Sanitation in the World's Cities (UN-HABITAT. 2010). http://www.unhabitat.org/pmss/listItemDetails.aspx?publicationID=2918.

Report, World Population (Population Reference Bureau, 2011). http://www.prb.org/ Population Reference Bureau. April 2011. World Population. http://www.prb.org/

2. Report, Global Food Waste Management, (World Biogas Association, 2018) http://www.worldbiogasassociation.org/wp-content/uploads/2018/05/Global-FoodWaste-Management-Full-report-pdf.pdf

3. E.C. Rada, L. Squazardo, G. Ionescu, A. Badea, UPB Sci. Bull. Serie D, 76, 199-206, (2014).

4. G Ionescu., E. C. Rada,L. I. Cioca, Environmental Engineering \& Management Journal (EEMJ), 14 (11) (2015)

5. Report, Estimates of European food waste levels, https://ec.europa.eu/food/safety/food_waste_en (EC, 2016)

6. A. N., Izaharuddina Paula, M. C., Theppitakb, S., Daib, X., \& Yoshikawab, K., Food waste gasification through hydrothermal carbonization pre-treatment, (Joint Meeting the German and Italian Sections of the Combustion Institute, 2018)

7. AA. Erakhrumen, Biomass gasification: Documented information for adoption/adaptation and further improvements toward sustainable utilisation of renewable natural resources, ISRN Renewable Energ. 8 (2012).

8. R. N. Tirtea, , C. Mărculescu, A. Badea, University Politehnica Of Bucharest Scientific Bulletin Series C-Electrical Engineering And Computer Science, 79(1), 315322, (2017).

9. S. Ciuta, D. Tsiamis, , M. J. Castaldi, Gasification of waste materials: technologies for generating energy, gas, and chemicals from municipal solid waste, biomass, nonrecycled plastics, sludges, and wet solid wastes. Academic Press, (2017).

10. T. Wongsiriamnuay T, N. Kannang, N. Tippayawong, Effect of operating conditions on catalytic gasification of bamboo in a fluidized bed, I. J. Chem. Eng. 9 (2013).

11. R. Nicoleta Tirtea, G. Ionescu, C. Bulmau, C. Marculescu, Experimental study of food court waste air gasification process performances in a batch reactor, $8^{\text {th }}$ International 
Conference on Thermal Equipment, Renewable Energy and Rural Development (TERE-RD), 2019 (Under review)

12. R. N. Tîrtea, C. Mărculescu, A. Badea, 2015 International Conference on ENERGY and ENVIRONMENT (CIEM) (2015)

13. I. Stănciulescu, , C. Mărculescu, D. Boldor, 2018 IEEE International Conference on Environment and Electrical Engineering and 2018 IEEE Industrial and Commercial Power Systems Europe (EEEIC/I\&CPS Europe), 1-4 (2018)

14. C. Bulmău, C. Mărculescu, S. Lu, Z. Qi, Journal of Geochemical Exploration 147, 298305 (2014)

15. C. Mărculescu, S. Ciuta, Renewable energy 57, 645-652 (2013)

16. R. N. Tirtea, I. Stanciulescu, G. Ionescu, C. Bulmau, C. Marculescu, D. Boldor, 2017 International Conference on ENERGY and ENVIRONMENT (CIEM), 390-393 (2017)

17. C. Stevens, Thermochemical processing of biomass: conversion into fuels, chemicals and power. Ed. Robert C. Brown. John Wiley \& Sons, 2011

18. W. De Jong, J. Ruud van Ommen, Biomass as a sustainable energy source for the future: Fundamentals of conversion processes. John Wiley \& Sons, 2014

19. C. Higman, M. van der Burgt, Gasification, f Professional Publishing, 2008

20. M. L. de Souza-Santos, Solid Fuels Combustion and Gasification: Modeling, Simulation. CRC Press, 2010

21. C. Bulmău, G. Ionescu and C. Mărculescu, Bio-Gaseous Fuels from Agricultural Waste Pyrolysis (Part II), 9th International Conference on Manufacturing Science and Education (MSE) 2019, (Accepted for publication) 